Journal of Business Management and
Economic Research
2018, 2(10): 1-14 DOI: $10.29226 / T R 1001.2018 .66$
Journal Homepage: https://www.jobmer.org

\title{
Determinants of Gross Domestic Saving: An Evidence from Asian Countries
}

\author{
Muhammad Imran Khan \\ School of Economics, Northeast Normal University, Changchun, Jilin, China \\ imranhaleem89@gmail.com

\section{Jian-Zhou Teng} \\ School of Economics, Northeast Normal University, Changchun, Jilin, China \\ Muhammad Kamran Khan \\ School of Economics, Northeast Normal University, Changchun, Jilin, China \\ Muhammad Rehan \\ School of Economics, Northeast Normal University, Changchun, Jilin, China \\ Ignatius Abasimi \\ School of Economics, Northeast Normal University, Changchun, Jilin, China
}

\begin{abstract}
This paper investigates determinants of gross domestic saving of eighteen Asian countries. Eighteen Asian countries were selected, based on the availability of data from the year 19952016. Secondary panel data of the determinants of gross domestic saving were obtained from the official website of the World Bank. Different statistical techniques such as fixed effect model, descriptive statistics and correlation matrix were employed in this research study. The results of the secondary data revealed that gross domestic product, age dependency ratio, broad money and inflation have statistically significant effect on the gross domestic savings while Tax revenue have non-significant effect on gross domestic saving. Gross domestic product, broad money and tax revenue have positive effect on gross domestic saving while age dependency ratio and inflation have negative effect on gross domestic saving. It is recommended that government of selected countries should adopt proper policies for financial institutions in order to encourage saving behavior among the people of their countries.
\end{abstract}

Keywords: Gross domestic saving (GDS), gross domestic product (GDP), age dependency ratio (ADR), broad money (BM), Tax Revenue (TR) and inflation (CPI). 


\section{INTRODUCTION}

Domestic savings are important for the economic growth of every country. Saving is an important factor which finance investment, creates job opportunities and mainly improve the level of productivity in developing countries. Therefore, it would be vital to look at the factors which affect the level of gross domestic saving and improve the economic growth of a country. Gross domestic saving offers an important association between past, present and future economic growth (Kazmi, 1993). Gross domestic saving is gross domestic product minus final consumption expenditure. The savings of public sector, private corporate sector and household sector in a country is called gross domestic saving. Domestic saving helps in maintaining high growth rates through its effect on the capital formation and investment. According to (Nga, 2007) domestic saving plays a vital and collective role for the sustainability and growth of an economy because it encourage investment eliminate poverty and create employment opportunities for the citizens. Mboweni (2008) has stated in his study that high rate of saving is a safeguard which save economies from bankruptcy, devaluation of currency and inflation. The high rate or percentage of domestic saving plays a pivotal role for the economic growth because high rate of saving and their channelization to investment not only ensures the growth of the economy but it also creates employment opportunities for the citizens and also attract foreign investors for investment (Mboweni, 2008). According to (Khan, 1993) high rate of saving is required for every country for the purpose to achieve sustainable growth, capital formation and mobilization of domestic resources. In case of achievement of investment and growth rates targets, appropriate domestic saving rate is an essential and important component (Kazmi, 1993).

According to Lucas (1988) high rate of saving and related growth in wealth or capital formation can affect economic growth of the country very positively. The domestic saving rates in many Asian countries have been weakened. However as per the economic concepts $22-25 \%$ of domestic saving rate is essential for financial development of an economy. Solow (1956) concluded in his research work that growth of economy is influenced by the rate of saving because high rate of saving is important for the economic growth. The economic growth and capital formation is the main goal of every country because citizens of developed countries live with more comfortable and holding a better welfare than the citizens of developing countries. To reduce poverty, unemployment, inflation and to improve the level of per capita income are the main goals of every country.

This research study has focused the gross domestic saving of different countries i.e. China, Pakistan, Russia, Iran, Mongolia, Bangladesh, Thailand, Indonesia, Malaysia, Philippines, Georgia, Nepal, India, Vietnam, Turkey, Cambodia, Sri Lanka and Bhutan. This study has employed secondary data regarding determinants of gross domestic saving of the selected countries in the research. The data was collected for period of 1995-2016. Literature review related to dependent variable and all independent variables of study was compiled from published research papers and research reports of different research journals etc. The current research has focused gross domestic saving, gross domestic product, age dependency ratio, broad money, tax revenue and inflation.

Importance of this study arises due to significant role of gross domestic saving in growth of a nation's economy. Saving has provided important services for individuals of any state. The research study has examined the impact of key elements of gross domestic saving. The present research has used sufficient logical outline of gross domestic saving of China, Pakistan, Russia, Iran, Mongolia, Bangladesh, Thailand, Indonesia, Malaysia, Philippines, Georgia, Nepal, India, Vietnam, Turkey, Cambodia, Sri Lanka and Bhutan. This research work has examined the 
independent variables as base in several other research studies of similar area of research. This study has provided comprehensive framework and published literature regarding factors affecting gross domestic saving. The current study has identified the effect of gross domestic product, age dependency ratio, broad money, tax revenue and inflation on gross domestic saving of the selected countries. This study has evaluated the factors which have provided a ground for further studies on the role of determinants in term of gross domestic saving. The importance of gross domestic saving and its awareness has been recognized on international as well as on national levels because it has played central role in decreasing inflation of a country. In this study, data regarding elements which affect the rate of domestic saving in the selected countries i.e. China, Pakistan, Malaysia, Philippines, Georgia, Nepal, India, Vietnam, Turkey, Cambodia, Sri Lanka, Russia, Iran, Mongolia, Bangladesh, Thailand, Indonesia and Bhutan was compiled from secondary sources (Websites of World Bank). The effect of independent variables on dependent variable (Gross domestic saving) was evaluated and analyzed.

Domestic saving has received importance and attention from economists (i.e. research community and academic) due to its important role in economic development. Previously research studies have been conducted by Jappelli et al. (1994); Blomstorm et al. (1996); Gavin et al. (1997). Sinha et al. (1998) and Weller et al. (2010) on this topic of research. However previous studies have emphasized on domestic saving of one country or countries chosen from other different regions of the world. Our research study is different from other research studies in term of geographical location, sample, and number of countries. The present study has considered a sample of eighteen Asian countries.

\subsection{THEORETICAL BACKGROUND}

\section{The Life-Cycle Hypothesis (LCH)}

This theory was developed by Franco Modigliani and his student in the year 1950. Richard Brumberg, developed a theory which was based on the observations that the consumption decision of many people mainly depend on their available assets over their lifetime, and on their current life stage. Brumberg and Modigliani observed that people make up different kinds of assets at the initial stages of their working lives and use it after their retirements.

\section{Relative Income Hypothesis}

The Theory of relative income hypothesis was developed by James Duesenberry. This theory states that the behavior saving and consumption behavior of the people depends on their income level in relation to others than by abstract standard of living. The percentage of resources consumed by a person mainly depends on his percentile position within the income or resources distribution.

\section{The Permanent Income Hypothesis}

It is an economics theory which explains that how an agent extends utilization of resources over his lifetime. This theory was developed by Milton Friedman, it supposes that a consumption of a person at a point in time is determined not just by their available resources but it also depends on their expected future permanent income.

\section{LITERATURE REVIEW}

It is known fact that one element may not affect the rate of domestic saving. However, different elements together such as gross domestic product \& broad money growth rate of country, foreign direct investment, per capita income, inflation, age dependency ratio, macroeconomic certainty level, financial liberalization, and economic policy will influence the rate of domestic 
saving. Published Literature is available on saving pattern; determinants of domestic saving of various countries of the world .Important published literature on domestic saving is summarized as under:

Paxson. (1997) reported negative relation between per capita income and saving. Basely et al. (1998) revealed that opposite income effect was dominated by positive alternatives causes and therefore savings rates has optimistic link or relationship with rate of interest. Narayan et al. (2005) reported basic components of Oman's national savings, from the year 1977-2003 by means of bound testing approach and ARDL model. Aggregate saving was dependent variable in his study while domestic credit, rate of population, rate of per capita income, money supply rate, current account deficit and urbanization rate were independent variables in his research study. The results showed that domestic credit, current account deficit and urbanization rate has encouraged influence on rate of saving while urban population rates, money supply and rates of per capita income has negatively affected the savings rate of Oman.

Narayan and Narayan (2006) reported saving activities in Fiji during 1968-2000 via ARDL method to co-integration rectification model. In this research study dependent variable was aggregate saving while rate of interest, deficit of current account, and dependency ratio of age were independent variables. This research proposed that both on long term and short term basis, $1 \%$ increase in growing rate of per capita income enhanced the saving rate by 0.05 and $0.07 \%$. Which showed constructive effect on the rate of saving. Rate of real interest and rate of age dependency ratio revealed synthesis consequences with saving.

Vincelette (2006) studied the saving factors of Pakistan. The research has compiled data for the year 1973-2005. He employed the method of OLS regression. Rate of saving was considered as dependent variable while, income of financial development, rate of interest, financial policy and factors of demography as independent variables. The results illustrated that there was negative and important connection among development of financial sector and aggregate saving. Direct inverse connection among economic or monetary imbalances and saving on the other hand income and demographic factors have major effect on rate of saving.

Newman et al. (2008) conducted research study on causes of saving which emphasized that three different elements has affected domestic saving performance in Africa. In which one was the ability of a person or individual to save money as his disposable income. The $2^{\text {nd }}$ was the tendency to save as influenced by socio-cultural and financial elements like domestic expenses to educate offspring. However to save and return on saving was the third opportunity. In addition to that size of family has controversial and negative influence on individual savings signifying that grand families have more sources constrained than little one's with disposable earnings and assuredly a worse level of savings.

Abbas and Bashir (2010) reported the factors of National Savings for short and long term in Pakistan. Time series data was applied by the author for the period or time from 1972-2008 by using vector error correction model (VECM) and Johansson Co integration method. The descriptive factors that influence the rates of National Savings in long term were price index, interest rate, exports, workers remittance, public loans, consumer and government spending. In long term public loans were inversely connected to rate of saving while interest rates, export, consumer price index, workers remittance and Government spending have vital and constructive or positive effect on rates of national savings. The interest rates and workers remittance was positively related with saving rates for short period.

Imran et al. (2010) reported consumer price inflation, public loans, interest rates, government consumption and remittances were as main factors of national saving. They revealed that these independent variables owns long run connection with dependent variable i.e. national savings, 
somehow or other these variables are co-integrated. Weller and Rao (2010) conducted study on tax revenue and domestic savings. They reported direct relationship of tax revenue and domestic savings. Rehman et al. (2010) studied the causes of families saving and recognized that age has positive connection with rate of savings. Issahaku (2011) reported that age structure and properties does not have major influence on saving. Components which make families or domestic investment were expenditure and occupation.

Turner and Manturuk (2012) studied that how single, formal, and fundamental factors influence the procedures of decisions making which supported domestic savings in New York. The outcomes revealed the factors of single elements such as requirement of family, upbringing effect of individuals toward savings and their self-reliance in their capability to save. Formal elements allowances, disincentives, and structural values form households' trust in economic institutes and their readiness towards contributing in savings programs.

Girma et al. (2014) reported the causes of domestic savings in Oroomia region, Ethiopia. In this research study different nine important factors, explanatory variables of domestic savings were analyzed which contains family head's education status and level, profit, capital, income, access to credit services, training membership, contact with extension, forms of savings and saving objects. Samantaraya et al. (2014) used Autoregressive Distributive Lag (ARDL) techniques in their study in order to investigate those factors which influencing household savings in India during the year 1992 - 2012. Variables included in their study were age dependency ration, inflation, gross fiscal deficit-GDP, real GDP ratio, personal income tax to GDP ratio, share of agriculture in total GDP, and external terms of trade. They found the existence of a long run association between the variables. Income and age dependency showed a positive impact while interest rate and inflation were negative. The terms of trade and fiscal were insignificant in explaining household saving in India.

M.Imran Khan et al. (2017) investigated determinants of national saving in six south Asian countries including Sri Lanka, Nepal, Pakistan, Bangladesh, India and Bhutan. Panel data were used for econometrics analysis of the selected countries from the year 1989-2013. Results of their study indicates that inflation, tax and gross domestic product have statistically significant effect on the gross domestic savings while per capita income, interest, money supply growth and age dependency ratio have non-significant effect on gross domestic saving. Inflation, tax revenue and gross domestic product showed positive effect on gross domestic saving.

\section{RESEARCH METHODOLOGY}

\section{Panel Data}

Panel data were used for econometric analysis in order to examine the Determinants of gross domestic saving in China, Pakistan, Russia, Iran, Mongolia, Nepal, India, Vietnam, Turkey, Cambodia, Sri Lanka, Bangladesh, Thailand, Indonesia, Malaysia, Philippines, Georgia and Bhutan. With the features of heterogeneity, as compare to cross-sectional and time series regression, panel data technique has advantage over them. The method of panel data has furnished accurate information. The results obtained from panel data technique were more accurate and generalized because of less Co-linearity between the selected variables.

\section{Fixed Effect Model}

It is the kind of Panel data. In this research study fixed effects model has used for the robustness in the result because it shows vigorous average errors where Heteroskedasticity is available in data. According to Wooldridge (2001) fixed effect model furnish the imbalanced results in 
regression model, generated due to omitted variables. Intercepts are different for people while coefficient's slopes are constant in fixed effects model Gujrati (2003); Baltagi (2008).

\section{Random Effect Model}

Random effect $\mathrm{h}$ is the most important type of panel data analysis. In this model the mean of all intercepts of the cross sectional units is the value of intercepts. It was applied for robust errors, where Heteroskedasticity was found in data.

\section{Chow Test}

This test was applied to select among Fixed Effects Model and Pooled regression Model.

\section{Breush-Pagan Test}

For selecting between pooled Model and Random Effects Model, Breusch-Pagan Test has been used in this research study.

\section{Hausman Test:}

In this research study Hausman test (1978) was applied to select among Fixed Effects Model and Random effect model.

\section{Regression Model}

Below is the model which was used for the assessment of present research study.

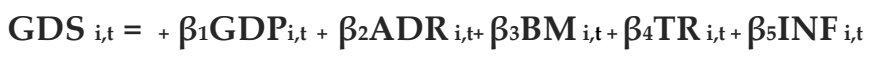

Where

$i$ is for country.

$t$ is for year

GDS: Growth of gross domestic saving

GDP: Gross Domestic Product

ADR: Age Dependency Ratio

BM: Broad Money

TR: Tax Revenue

INF: inflation rate

While, $\alpha$ : constant $\beta 1, \beta 2, \beta 3, \beta 4$ and $\beta 5$ are called the regression coefficients, and $\mathcal{E}$ is the random error terms.

\section{Dependent Variable}

\section{Domestic Saving}

Gross domestic saving is the dependent variable of this research study. The percentage or rate of gross domestic product (GDP) held by households in a country is called gross domestic saving (GDS). The overall private corporate and public saving in the form of liquid assets in a country is called domestic savings. An adequate domestic saving rate is an essential condition for attainment of investment or capital formation and growth rate target of a country. (Kazmi, 1993). Saving is a shield which protects economies from bankruptcy. (Mboweni, 2008).

\section{Independant Variables}




\section{Gross Domestic Product}

The value of all finished commodities or products and services produced in a state or country in a particular time (i.e. one year) is known as Gross Domestic Product. There is a positive and durable connection among growth and domestic saving. According to Maddison (1992) and Bosworth (1993) GDP has constructive relationship with the rate of saving and economic growth.

\section{Age Dependency Ratio}

Age dependency ratio is the percentage of dependents which includes from people younger than 15 or older than 64, to the working-age population (ages 15-64). According to previous relevant research studies it seems that demographics (size, age and structure of households) affect the rate of domestic saving of a country. According to Modigliani (1970) people save more and more money at the middle age as compare to young or old age. The proportion of the working age population to total population of a country is called the percentage of age dependency ratio. According to Masson et.al. (1998) countries with high percentage of working age population present high saving percentage rate as compared with other nations with minimum ratio of working age population.

\section{Broad Money}

Brookin (2001); Narayan and Siyabi (2005) reported in their researches that money supply (M2) have opposite and inverse connection or link with aggregate savings. As money supply will increase then aggregate savings will be decreased.

\section{Tax Revenue}

All type of Excise duty and custom duty plus Interests and Penalties collected by government itself depend on Provincial and Local Government to perform as its gathering facilitators. Weller and Rao (2010) conducted a study on tax revenue and domestic savings, the result showed that they have direct relationship among each other. The tax revenue has positive relationship with national savings.

\section{Inflation (Cpi)}

It can be defined as when prices of commodities increase and value of money decrease in an economy. When prices of commodities rises, individuals have to consume extra on purchasing which declines the amount of domestic saving which reveals negative trend. According to (Kazmi, 1993) that there exists a negative connection among inflation and domestic saving.

\section{RESULTS AND DISCUSSION}

\section{Descriptive Statistics}

\begin{tabular}{|l|l|c|c|c|c|}
\hline VARIABLES & OBS & MEAN & S.D & MIN & MAX \\
\hline GDS & 396 & 25.11458 & 11.92634 & -12.79198 & 51.25779 \\
\hline GDP & 396 & 5.452594 & 3.553076 & -13.12673 & 17.92582 \\
\hline ADR & 396 & 56.91351 & 13.11578 & 35.59041 & 98.05256 \\
\hline BM & 396 & 61.82837 & 38.35612 & 6.82303 & 208.3067 \\
\hline TR & 396 & 12.42009 & 4.333958 & 4.994378 & 28.70997 \\
\hline INF & 396 & 9.939888 & 17.32484 & -18.10863 & 197.147 \\
\hline
\end{tabular}

The above tables reveals descriptive statistics such as mean, standard deviation, minimum and maximum of gross domestics savings (GDS), gross domestic product, age dependency ratio, 
broad money, tax revenue and inflation during the period from 1995 to 2016 of eighteen different Asian countries i.e China, Pakistan, Iran, Mongolia, Malaysia, Russia, Bangladesh, Thailand, Indonesia, Philippines, Georgia, Nepal, India, Vietnam, Turkey, Cambodia, Sri Lanka and Bhutan. According to the above table gross domestics saving has mean value of $25.11 \%$ in gross domestic saving of the selected countries other variables such as gross domestic product, age dependency ratio, broad money, tax revenue and inflation 5.45, 56.9, 61.8, 12.4 and 9.93 respectively while the minimum values of gross domestics saving, gross domestic product, age dependency ratio, broad money, tax revenue and inflation are $-12.79,-13.12,35.5,6.82,4.99$ and -18.1 respectively. The maximum values of gross domestics saving, gross domestic product, age dependency ratio, broad money, tax revenue and inflation are 51.25, 17.9, 98.5, 208.3, 28.7 and 197.1 respectively.

\section{Correlation Matrix}

\begin{tabular}{|l|c|c|c|c|c|c|}
\hline Variables & GDS & GDP & ADR & BM & TR & INF \\
\hline GDS & 1.0000 & & & & & \\
\hline GDP & 0.1304 & 1.0000 & & & & \\
\hline ADR & -0.5254 & -0.0318 & 1.0000 & & & \\
\hline BM & 0.5869 & 0.1005 & -0.4280 & 1.0000 & & \\
\hline TR & -0.0175 & -0.0217 & -0.3407 & 0.1280 & 1.0000 & \\
\hline INF & -0.0831 & -0.2368 & -0.0039 & -0.2726 & -0.0400 & 1.0000 \\
\hline
\end{tabular}

The above table reveals the correlation matrix of dependent and independent variables for China, Pakistan, Iran, Mongolia, Malaysia, Russia, Bangladesh, Thailand, Indonesia, Philippines, Georgia, Nepal, India, Vietnam, Turkey, Cambodia, Sri Lanka and Bhutan for the period from 1995 to 2016. Gross domestic savings have positive correlation with gross domestic product and broad money, but have negative correlation with age dependency ratio, Tax revenue and inflation.

Chow Test

\begin{tabular}{|c|c|}
\hline S.No & Variables \\
\hline 1 & GDP $=0$ \\
\hline 2 & ADR $=0$ \\
\hline 3 & $\mathrm{BM}=0$ \\
\hline 4 & $\mathrm{TR}=0$ \\
\hline 5 & $\mathrm{INF}=0$ \\
\hline \multicolumn{2}{|c|}{} \\
\hline \multicolumn{2}{|c|}{ Chi2 $(5)=84.47$} \\
\hline
\end{tabular}

The above table shows result of chow test. This table was used for the selection purpose of fixed effect model and Pooled OLS Model. P Value of chow test indicates that P value is less than 0.05 so we reject null hypothesis because fixed effects model is more suitable than pooled regression model. 
Breusch And Pagan Lagrangian Multiplier Test

\begin{tabular}{|c|c|c|c|}
\hline & & Var & $\mathrm{SD}=$ sqrt (Var) \\
\hline GDS & & 142.2375 & 11.92634 \\
\hline$E$ & & 20.4322 & 4.5202 \\
\hline $\mathrm{U}$ & & 51.68923 & 7.189522 \\
\hline \multicolumn{2}{|r|}{$\operatorname{Var}(\mathrm{u})=$} & 0 & \\
\hline & $\operatorname{Chibar}^{2}(01)=$ & 1404.47 & \\
\hline & Prob $>$ Chibar $^{2}=$ & 0.0000 & \\
\hline
\end{tabular}

The above table indicates variation and standard deviation of gross domestic saving. The variation and SD of gross domestic saving (GDS) was 142.23 and 11.92 respectively. On the basis of p-value we reject null hypothesis which indicates that pooled OLS model is better than random effects model.

\section{Hausman Test}

\begin{tabular}{|l|c|c|c|c|}
\hline Variables & Fixed Effect & \multicolumn{1}{c}{ Random Effect } & \multicolumn{1}{l|}{ Var(Diff.) } & \multicolumn{1}{l|}{ Prob. } \\
\hline GDP & 0.272709 & 0.280152 & 0.000049 & 0.2876 \\
\hline ADR & -0.113456 & -0.115012 & 0.000092 & 0.8712 \\
\hline B & 0.043232 & 0.055705 & 0.000045 & 0.0622 \\
M & & & & 0.0195 \\
\hline TR & 0.063976 & 0.024447 & 0.000286 & 0.1477 \\
\hline INF & -0.030807 & -0.029327 & 0.000001 & \\
\hline
\end{tabular}

\begin{tabular}{|l|l|l|l|}
\hline Test Summary & Chi-Sq Statistic & Chi-Sq. d.f & Prob. \\
\hline Cross-section & 16.874442 & 5 & 0.0047 \\
\hline
\end{tabular}

The above table reveals the results of the Hausman specification test. This test was used for the purpose of selecting whether to use fixed effect model or random effect model. The p-value of chi $^{2}$ is .0047 which is less than .05 . Under this assumption fixed effect model is more efficient than random effect model.

\section{Fixed Effect Model}

\section{Dependent variable: GDS}

\begin{tabular}{|l|l|l|l|l|}
\hline & Coefficient & Std. Error & t-ratio & $p$-value \\
\hline Const & 26.92347 & 3.379058 & 7.967746 & 0.001 \\
\hline GDP & 0.272709 & 0.074310 & 3.669874 & 0.003 \\
\hline ADR & -0.113456 & 0.038076 & -2.979726 & 0.031 \\
\hline BM & 0.043232 & 0.019286 & 2.241646 & 0.025 \\
\hline TR & 0.063976 & 0.090891 & 0.703879 & 0.481 \\
\hline INF & -0.030807 & 0.015350 & -2.006939 & 0.045 \\
\hline R-squared & 0.864352 & Adjusted R-squared & 0.856352 \\
\hline F Statistic & 108.0349 & P-value (F) & 0.00000 \\
\hline
\end{tabular}

In the above table, results of the fixed effects model are presented. It can be observed that gross domestic product, age dependency ratio, broad money and inflation were statistically significant because the $P$ value of these variables are less than 0.05 i.e. $0.003,0.031,0.025$ and 0.045 respectively. The value of $\mathrm{R}$-squared shows that independent variables explains $86 \%$ of 
the entire panel's variation. The coefficient of fixed effect model shows that gross domestic product, broad money and tax revenue have positive effect on gross domestic saving while age dependency ratio and inflation, have negative effect on gross domestic savings.

Gross domestic product is statistically significant and coefficient of gross domestic product shows positive effect on gross domestic savings. Results of gross domestic product are same to the results of the Mckinnon (1973) and Shaw (1973) they revealed that increase in the interest rate of savings boost up gross domestic product. Our results verify the results of Agarwal (2001), he analyzed the savings behavior of seven Asian countries. He concluded that most of the countries have shown significant impact of Gross Domestic Product on savings.

Age dependency ratio are statistically significant and coefficient of age dependency also show negative effect on gross domestic saving. Results of age dependency are same to the results of Masson et.al. Masson et.al (1998) concluded that the countries which have high ratio of working age population present high savings rate as compared to countries which have low ratio of working age population. As concluded from these studies countries like China are experiencing increasing savings rate as their young dependency population is increasing. They indicated positive and significant relationship among age dependency and saving in China.

Broad Money was statistically significant and have positive effect on gross domestic saving. Result of money supply was same to the results of of Joshi. Joshi (2007) conducted investigation on the domestic savings, capital account of the balance of payment. He used explanatory variables for the study of capital formation. The long run steady state relationship between various component of saving capital account balance and gross domestic capital formation was estimated. It was pointed out that money supply increase the capital formation and growth in economy and lead to saving. Joshi (2007) revealed significant relationship among saving and money supply.

Tax revenue have positive effect on gross domestic saving of the selected Asian countries. But the results of tax revenue has non-significant effect on gross domestic saving. Our study results are same with Rao (2010). He conducted a study on tax revenue and domestic savings, the result showed that they have direct relationship among each other. The tax revenue has positive relationship with National Savings.

Inflation has negative effect on gross domestic savings and having statistical significant value. Our result of inflation is similar with the results of Muradoglu et al. Muradoglu et al (1996) aimed at examining the differences in household savings behavior in developing and industrial countries from a cross-country perspective. The purpose of their study was to learn more about differences in nature of the household savings behavior in industrial versus developing countries. Income, wealth, rate of returns, inflation, foreign savings, and demographic variables were taken as the determinants of savings. Their results indicated that inflation has significant relationship with savings.

\section{CONCLUSIONS \& RECOMMENDATIONS}

This research study " determinants of gross domestic saving: an evidence from Asian countries was aimed to examine the important factors of domestic saving such as gross domestic product, age dependency ratio, broad money, tax revenue and inflation from 1995 to 2016. This research study was mainly based on secondary data compiled from "websites of World Bank". Determinants of gross domestic saving such as gross domestic product, age dependency ratio, broad money and inflation were statistically significant. The coefficient of fixed effect model shows that gross domestic product, broad money and tax revenue have 
positive effect on gross domestic saving while age dependency ratio and inflation, have negative effect on gross domestic savings.

Based on outcome of this study, the major recommendations are presented as under:

It is suggested that in future research scholars may use primary data for research studies on the topic of gross domestic saving because the primary data will depict accurate impact of the determinants on gross domestic saving in different Countries of the world. Maximum independent variables will generate more valuable and accurate reports which may improve understanding on the subject as well as quality of future research studies.

Proper policies may be framed and adopt for financial institutions by the selected countries in the study for the purpose to achieve main goal of economic growth, capital formation. On the other hand Policies of income effect and prices effect should be presented and adopted for constructive changes in behavior of saving.

Governments of these countries may also adopt different kinds of policies for stimulating investment, encourage saving and increase production in order to achieve the goal of economic growth.

\section{References}

Agrawal, P. (2001). The relation between savings and growth: cointegration and causality evidence from Asia. Applied economics, 33(4), 499-513.

Ando, A., \& Modigliani, F. (1963). The" life cycle" hypothesis of saving: Aggregate implications and tests. The American economic review, 53(1), 55-84.

Aron, J., \& Muellbauer, J. (2009). 15. Monetary policy and inflation modeling in a more open economy in South Africa. Monetary Policy Frameworks for Emerging Markets, 275.

Attanasio, O. P., Picci, L., \& Scorcu, A. E. (2000). Saving, growth, and investment: a macroeconomic analysis using a panel of countries. Review of Economics and Statistics, 82(2), 182-211.

Basely, T., \& Meghir, C. (1998). Do Tax Incentives Raise Private Saving?. World Bank Document.

Blomström, M., Lipsey, R. E., \& Zejan, M. (1996). rIs Fixed Investment the Key to Economic Growth. sQuarterly Journal of Economics, 111.

Bonham, C., \& Wiemer, C. (2012). Chinese saving dynamics: the impact of GDP growth and the dependent share. Oxford Economic Papers, 65(1), 173-196.

Bosworth, B. P. (1993). Saving and investment in a global economy.

Botha, F., Simleit, C., \& Keeton, G. (2011). The determinants of household savings in South Africa. Studies in Economics and Econometrics, 35(3), 1-20.

Carroll, C. D., \& Weil, D. N. (1994, June). Saving and growth: a reinterpretation. In CarnegieRochester conference series on public policy (Vol. 40, pp. 133-192). North-Holland.

Chaudhry, I., Faridi, M. Z., Abbas, M., \& Bashir, D. (2015). Short run and long run saving behavior in Pakistan: An empirical investigation.

Corbo, V., \& Schmidt-Hebbel, K. (1991). Public policies and saving in developing countries. World Bank Publications. 
Denizer, C., \& Wolf, H. C. (2000). The savings collapse during the transition in Eastern Europe. The World Bank.

Edey, Malcolm, and Luke Gower. (2000): National saving: trends and policy." In The Australian Economy in the 1990s, papers from the annual Reserve Bank of Australia conference, pp. 24-25.

Faridi, Muhammad Zahir, and Furrukh Bashir. (2010): Households Saving Behaviour in Pakistan: A Case of Multan District." Pakistan Journal of Social Sciences (PJSS) 30.

Friedman, Milton. (1957): A theory of the consumption function: A study by the National Bureau of Economic Research. Princeton University Press.

Fuller, Kathleen, and Benjamin M. Blau. (2010): Signaling, free cash flow and "nonmonotonic" dividends." Financial Review 45, no. 1 21-56.

Gale, William G., and Peter R. Orszag. (2004): Budget deficits, national saving, and interest rates." Brookings Papers on Economic Activity 2004, no. 2 101-210.

Gavin, M., Hausmann, R. and E. Talvi (1997): Saving behavior in Latin America: Overview and Policy issues, In: Hausmann, R., Reisen, H. (eds), Promoting Savings in Latin America. Organization for Economic Cooperation and Development and Inter-America Development Bank, Paris..

Giovannini, Alberto. (1985): Saving and the real interest rate in LDCs." Journal of Development Economics 18, no. 2-3: 197-217.

Gujarati, Damodar N. (2012): Basic econometrics. Tata McGraw-Hill Education.

Hausman, Jerry A. (1978): Specification tests in econometrics." Econometrica: Journal of the Econometric Society 1251-1271.

Heer, Burkhard, and Bernd Süssmuth. (2009): The savings-inflation puzzle." Applied Economics Letters 16, no. 6 615-617.

Hussain, Mumtaz, and Oscar T. Brookins. (2001): On the determinants of national saving: An extreme-bounds analysis." Review of World Economics 137, no. 1 150-174.

Irshad Ali., Ibrahim and Owais Ahmad. (2014): Effect of tax revenue on national saving of Pakistan. "International Journal of Economics.

Jappelli, T and M. Pagano (1994): Savings, Growth and Liquidity Constraints, Quarterly Journal of Economics, 109: 83-109.

Joshi, Himansu. (2007): The role of domestic saving and foreign capital flows in capital formation in India." RBI Occasional Papers 28, no. 3.

Kazmi, A. A., \& Bilquees, F. (1993). National Savings Rates of India and Pakistan: A Macro econometric Analysis [with Comments]. The Pakistan Development Review, 32(4), 13131324.

Kazmi, Aqdas Ali. (2001): A Study on Saving Functions for Pakistan: The Use and Limitations of Econometric Methods.

Khan, Ashfaque H., Lubna Hasan, Afia Malik, and Beatrice Knerr. (1992): dependency ratio, foreign capital inflows and the rate of savings in Pakistan [with comments]." The Pakistan Development Review 31, no. 4 843-856. 
Khan, Naheed Z., Eric Rahim, and Zafar Mahmood. (1993): Foreign Aid, Domestic Savings and Economic Growth (Pakistan: 1960 to 1988)[with Comments]." The Pakistan Development Review32, no. 4 1157-1167.

Khan, Saleem M. (1993): Domestic resource mobilization: a structural approach." The Pakistan Development Review 32, no. 4 1067-1078.

Kim, Myeong Hwan. (2010): The Determinants Of Personal Saving In The US." Journal of Applied Business Research (JABR) 26, no. 5.

Komicha, Hussien Hamda.(2007): Farm household economic behavior in imperfect financial markets. Vol. 2007, no. 78.

Kulikov, Dmitry, Annika Paabut, and Karsten Staehr (2007): A Micro econometric Analysis of Household Saving in Estonia: Income, Wealth and Financial Exposure. Eesti Pank.

Loayza, Norman, Klaus Schmidt-Hebbel, and Luis Servén. (2000): What drives private saving across the world?" The Review of Economics and Statistics 82, no. 2 165-181.

Lucas, Robert E. (1988): On the mechanics of economic development." Journal of monetary economics 22, no. $13-42$.

M.Imran Khan et al (2017). Determinants of national saving: an evidence from south Asian countries "European Academic Research vol. v, Issue 8/ November 2017".

Maddison, Angus. (1992): A long-run perspective on saving." The Scandinavian Journal of Economics: 181-196.

Mahlo. N. (2011). Determinants of household savings in South Africa. University of Johannesburg.

Masson, Paul R., Tamim Bayoumi, and Hossein Samiei. (1998) "International evidence on the determinants of private saving." The World Bank Economic Review 12, no. 3 483-501.

Mboweni, T. (2008): Monetary Policy, Inflation targeting and inflation pressures: in address by Governor of the south African Reserve Bank, to the Bureau for Economic Research Annual Conference, Johannesburg.

McKinnon, Ronald (2010): Money and capital in economic development. Brookings Institution Press,.

Modigliani, Franco. (1970): The life cycle hypothesis of saving and intercountry differences in the saving ratio." Induction, growth and trade : 197-225.

Modigliani, Franco. (1986): Life cycle, individual thrift, and the wealth of nations." The American Economic Review 76, no. 3 297-313.

Muradoglu, Gulnur, and Fatma Taskin (1996): Differences in household savings behavior: evidence from industrial and developing countries." The Developing Economies 34, no. 2 (1996): 138-153.

Narayan, Paresh Kumar, and A. L. Saud.: (2005):An empirical investigation of the determinants of Oman's national savings." Economics Bulletin 3, no. 51: 1-7.

Narayan, Paresh Kumar, and Seema Narayan. (2006) : Savings behavior in Fiji: an empirical assessment using the ARDL approach to cointegration." International journal of social economics 33, no. 7 468-480. 
Nga, M. T. (2007). An investigative analysis into the saving behaviour of poor households in developing countries: with specific reference to South Africa (Doctoral dissertation, University of the Western Cape).

Ozcan, Kivilcim Metin, Asli Gunay, and Seda Ertac. (2003):Determinants of private savings behaviour in Turkey." Applied Economics 35, no. 12 1405-1416.

Paxson, Christina H., and Angus Deaton. (1997): Saving, growth, and aging in Taiwan. National Bureau of Economic Research,

Samantaraya,A., and Patra,S. (2014): Determinants of Household Savings in India: An Empirical Analysis Using ARDL Approach. Economics Research International..

Samwick, Andrew A. (2000): "Is pension reform conducive to higher saving?." The Review of Economics and Statistics 82, no. 2 264-272.

Schultz, T. Paul. (2005):Demographic determinants of savings: estimating and interpreting the aggregate association in Asia..

Sinha, D., \& Sinha, T. (1998). Cart before the horse? The saving-growth nexus in Mexico. Economics Letters, 61(1), 43-47.

Solow, R. M. (1956). A contribution to the theory of economic growth. The quarterly journal of economics, 70(1), 65-94.

Syden, M. (2014). Trends and determinants of household saving in South Africa. Economic Affairs, 59(2), 191.

Teshome, G., Kassa, B., Emana, B., \& Haji, J. (2014). Saving patterns of rural households in east hararghe zone of Oromia National Regional State, Ethiopia. Journal of Development and Agricultural Economics, 6(4), 177-183.

Vincelette, G. A. (2006). Determinants of saving in Pakistan. The World Bank.

Weller, C. E., \& Rao, M. (2010). Progressive tax policy and economic stability. Journal of Economic Issues, 44(3), 629-659.

Wooldridge, J. M. (2010). Econometric analysis of cross section and panel data. MIT press. 